\title{
Pola Pertumbuhan Pseudomonas aeruginosa untuk Retting-Embun Serat Kasar pada Tanaman Lidah Mertua (Sansevieria trifasciata)
}

\section{The Growth Pattern of Pseudomonas aeruginosa for Bioretting of Crude Fiber in Sansevieria trifasciata}

\author{
Eka Prasetyowati $\left.{ }^{*}\right)$, Ahmad Syauqi ${ }^{2 * *}$, Tintrim Rahayu ${ }^{3}$ \\ ${ }^{123}$ Jurusan Biologi, Fakultas Matematika dan Ilmu Pengetahuan Alam, \\ Universitas Islam Malang, Indonesia
}

\begin{abstract}
ABSTRAK
Sansivieria trifasciata memiliki dinding sel yang terdiri dari komponen selulosa tinggi yang diperkuat oleh lignin, pektin dan hemiselulosa. Pemisahan serat dari ikatan yang memperkuat serat masih menjadi masalah utama karena dinding sel yang dimiliki sangat kuat dan kaku. Dalam kegiatan pemisahan serat selolusa perlu adanya proses yang dinamakan retting. Residu dari proses retting dengan bahan kimia dapat mencemari lingkungan, pemisahan dengan cara mekanik menghasilkan serat yang masih kaku, dan dengan perendaman membutuhkan air yang cukup banyak serta menimbulkan bau. Tujuan dari penelitian ini adalah berapa lama Pseudomonas earuginosa yang digunakan dapat menunjukkan perkembangbiakan sel, mendapatkan grafik pola pertumbuhan pada sediaan daun Sansevieria trifasciata dengan penambahan nutrisi dan kualitas serat dari retting-embun. Penelitian ini menggunakan metode eksperimen, terdapat 2 perlakuan yaitu penambahan nutrisi dan tanpa nutrisi dengan 6 ulangan waktu 5 hari, 10, hari, 15 hari, 20 hari dan 30 hari. Hasil dari penelitian ini jumlah sel perlakuan dengan penambahan nutrisi dan tanpa penambahan nutrisi mengalami fase lag hari ke-5 sampai hari ke-10 dan fase eksponensial dimulai dari hari ke-10 sampai hari ke-30. Pseudomonas aeruginosa dapat melunakkan dinding sel dengan kemampuan rettingembun diperoleh skor 3,0 perlakuan nutrisi dan skor 1,5 parlakuan tanpa nutrisi. Pada analisa regresi $F_{\text {hitung }} \geq F_{\text {tabel }}$, dimana adanya pengaruh yang signifikan kepada jumlah sel setiap unitnya dengan penambahan nutrisi dan tanpa penambahan nutrisi.
\end{abstract}

Kata kunci: Pola Pertumbuhan, Pseudomonas aeruginosa, Serat Kasar dan Sansevieria trifasciata

\section{ABSTRACT}

Sansivieria trifasciata has a cell wall consisting of high cellulose components which are reinforced by lignin, pectin and hemicellulose. Separation of fibers from bonds that strengthen fibers is still a major problem because the cell walls that are owned are very strong and stiff. In the activity of separating selolusa fiber there needs to be a process called retting. Residues from the retting process with chemicals can pollute the environment, separation by mechanical means produces fibers that are still rigid, and with soaking requires a lot of water and causes odor. The purpose of this study is how long the Pseudomonas earuginosa used can show cell proliferation; get a graph of growth patterns in Sansevieria trifasciata leaf preparations by adding nutrients and fiber quality from dew retting. This study uses an experimental method; there are 2 treatments, namely the addition of nutrition and without nutrition with 6 replications time 5 days, 10, days, 15 days, 20 days and 30 days. The results of this study were the number of treated cells with the addition of nutrients and without the addition of nutrients experiencing the lag phase of the 5th to 10th day and the exponential phase starting from the 10th day to the 30th day. Pseudomonas aeruginosa can soften the cell wall with dew-retting ability obtained by 3.0 nutritional treatment scores and a score of 1.5 treatments without nutrition. In the regression analysis $F_{\text {count }} \geq F_{\text {table }}$, where there is a significant influence to the number of cells per unit and the addition of nutrients and without the addition of nutrients.

Keywords: Growth Pattern, Pseudomonas aeruginosa, Coarse Fiber and Sansevieria trifasciata

*) Eka Prasetyowati, Jurusan Biologi, FMIPA/UNISMA, Jl. Mt. Haryono 193, Malang 65144.,

Telp.082334061568 and e-mail: lailahmahbubah@gmail.com

${ }^{* *}$ Ir. Ahmad Syauqi, M.Si, Jurusan Biologi, FMIPA/UNISMA, J1. Mt. Haryono 193, Malang 65144.

Telp.08986307836 and E-mail: syauqi.fmipa@unisma.ac.id

Diterima Tanggal 26 Juli 2019 dan Publikasi Tanggal 20 Agustus 2019 


\section{Pendahuluan}

Pemanfaatan serat alam sebagai bahan komposit terus dikembangkan oleh para peneliti, mulai dari serat ramie, pandan, abaca, sisal, nanas, kenaf dan lain-lain yang ditujukan pada aplikasi dibidang industri otomotif maupun elektronik. Serat daun lidah mertua (Sansevieria trifasciata) merupakan tanaman dari famili Liliaceae dan salah satu jenis tanaman yang perlu diteliti, melihat tanaman ini mudah untuk dibudidayakan dan memiliki potensi yang sangat baik sebagai penguat komposit [1].

Kebanyakan serat alam (kecuali kapas) terdiri dari mikrofibril selulosa kristal kaku yang diperkuat oleh lignin, hemiselulosa dan pektin. Dalam pemisahan serat dari ikatan yang memperkuat serat sangat sulit dilakukan karena dinding sel yang dimiliki sangat kuat dan kaku sehingga perlu adanya teknik perlakuan. Lignin memiliki senyawa yang sangat komplek dan berat molekul yang tinggi membuat dinding menjadi kaku. Selain itu lignin membuat mutu serat kurang baik, sehingga perlu ada perlakuan dalam memperbaiki mutu serat. Hemiselulosa berfungsi sebagai perekat dan mempercepat pembentukan serat. Apabila tidak terdapat hemiselulosa, maka akan mengakibatkan berkurangnya ikatan antar serat dan adanya lubang antar fibril [2]. Selain lignin dan hemiselulosa, di antara dinding sel primer terdapat lamela tengah atau ruang antar sel yang kaya akan polisakarida lengket yang dinamakan dengan pektin. Ketika sel berhenti tumbuh, maka pektin akan memperkuat sel [3].

Dalam kegiatan pemisahan serat memerlukan proses yang di namakan retting. Proses retting dapat dilakukan dengan cara perendaman, mekanis dan kimiawi. Perendaman (bioretting) yang dilakukan kurang efektif dan efisien, karena memerlukan lahan air yang cukup luas dan sisa air retting dapat mencemari lingkungan. Retting secara mekanis, menghasilkan serat yang terlalu kaku walaupun dalam memproduksi serat lebih ekonomis. Pemisahan serat secara kimiawi, dengan menggunakan senyawa asam maupun basa yang berfungsi untuk mendegradasi senyawa non-selulosa yang mengikat serat di dinding sel. Teknik ini menghasilkan serat yang kurang bagus dan residu kimiawi selama proses retting menimbulkan polusi, sehingga dianggap tidak ramah lingkungan [4].

Bakteri yang mampu dalam proses perombakan tanaman serat menjadi serat adalah genera Arthrobacter, Flavobacterium, Micrococcus, Pseudomonas, Xanthomonas, Achromobacter, Mycobacterium, Thermomonospora, Streptomyces, Micromonospora, Microbispora, Amycolata dan Nocardia [5]. Berdasarkan penelitian pada referensi [6] tentang isolasi dan identifikasi bakteri selulolitik dan paktinolitik dalam limbah kulit singkong didapatkan hasil Pseudomonas aeruginosa tidak dapat menghidrolisis selulosa pada media CMC (Carbocymethylcellulosa) dan memiliki kandungan pektinolitik yang didapatkan zona bening pada media VA (Vincent's Agar) yang mengindikasi kemampuannya dalam menghidrolisis pektin.

Dengan permasalahan pada retting perlu dikembangkan saat ini adalah retting-embun yaitu secara mikrobiologi (bioretting). Penambahan bakteri Pseodomonas aeruginosa diharapkan sebagai biodegradability terhadap pektin, hemiselulosa dan lignin, serta dapat menyelamatkan lingkungan dari pencemaran rendaman pada perolehan serat dan diharapkan mampu meningkatkan efektifitas retting pada kondisi air terbatas. Fungsi dan peran mikroorganisme adalah mendekomposisi bahan organik melalui mekanisme kerja ensim yang dimiliki oleh mikroba. Hal itu secara spesifik berdasarkan $\mathrm{pH}$ optimum tertentu sesuai ensimnya seperti ensim kategori unik yang bekerja pada karbohidrat [7]. Oleh karena itu dilakukan penelitian ini dengan tujuan berapa lama Pseudomonas earuginosa yang digunakan dapat menunjukkan perkembangbiakan sel, mendapatkan grafik pola pertumbuhan pada sediaan daun Sansevieria trifasciata dengan penambahan nutrisi dan kualitas serat dari retting-embun.

\section{Material dan Metode}

\section{Bahan dan Alat}

Bahan yang digunakan pada penelitian ini adalah MCA (MacConkey Agar) (Merk: Himedia) 49,53 g/l, NB (Nutrient Borth) (Merk: Nutrient Borth for Microbiology) 8 g/l, HCl 1\% (Hidrogen Klorida), $\mathrm{NaOH}$ 0,1 N (Natrium Hidroksida), aquades steril, alkohol 70\%, daun lidah mertua 
(Sansevieria trifasciata) dan isolat bakteri Psedomonas aeruginosa yang diperoleh dari laboratorium Mikrobiologi, Fakultas Kedokteran, Universitas Brawijaya Malang.

Alat yang digunakan pada penelitian ini adalah kulkas, timbangan analitik, Colony counter, $\mathrm{pH}-$ Meter, oven, autoclave, hot plate magnetic stirrer, inkubator, laminar air flow, gelas beaker, gelas ukur, erlenmeyer, cawan petri, tebung reaksi, rak tabung reaksi, pipet tetes, batang ose, jarum ose ujung bulat, bunsen, pisau, tissue, warp, kapas, karet, kertas payung, kertas tempel, penggaris, bolpoin, spidol, plastik, bak plastik, gunting, aluminium foil, dan gelas pengaduk.

\section{Metode}

Penelitian ini menggunakan metode eksperimen dengan rancangan dua perlakuan pada analisis regresi tingkat kepercayaan 95\% [8]. Terdapat 2 perlakuan, yaitu penambahan nutrisi (Pseudomonas aeruginosa $+\mathrm{NB}$ ) dan perlakuan kontrol (Pseudomonas aeruginosa + aquades steril) dengan 6 ulangan waktu, yaitu 5 hari, 10 hari, 15 hari, 20 hari, 25 hari dan 30 hari. Setiap perlakuan diulang sebanyak 6 kali ulangan. Analisis/sidik ragam regresi dilakukan pada kepercayaan $95 \%$. Selanjutnya penilaian pada hari ke 30 dilakukan berdasarkan terpisahnya serat, dengan nilai skor $0=$ daun masih utuh, $1=$ serat mulai terpisah dari bentuk daun, 2 = serat terpisah dari bentuk daun dan sebagian telah terpisah satu sama lain, dan $3=$ serat telah sepenuhnya terpisah satu sama lainnya [9].

\section{Cara Kerja}

Persiapan: Mencuci botol, cawan petri, skapel, pinset, erlenmeyer, gelas ukur, gelas beaker, tabung reaksi dan alat lainnya cuci bersih dengan deterjen hingga tanpa titik air. Kering anginkan serta lengkapi dengan tutup kapas, tali serta kertas sampul cokelat atau aluminium foil. Sterilkan pada suhu $121^{\circ} \mathrm{C}$ selama 15 menit. Setelah sterilisasi dengan menggunakan autocave, memasukkan alat-alat ke dalam oven dengan suhu $100^{\circ} \mathrm{C}$.

Pembuatan Media: Medium yang akan digunakan adalah MCA (Mac Conkey Agar) 49,53 gr $1^{-1}$ dan NB (Nutrient Borth) $40 \mathrm{gr}^{-1}$. Kemudian dihomogenkan dengan menggunakan hotplate magnetic stirrer di Erlenmeyer sampai mendidih, ditutup dengan menyumbat kapas, kertas sampul dan tali atau aluminium foil. Sterilkan pada suhu $121^{\circ} \mathrm{C}$ selama 15 menit.

Pengambilan Sampel Sansevieria trifasciata: Dalam pengambilan sampel dilakukan dengan cara aseptik. Sebelum memotong daun, tangan disemprot dengan alkohol $70 \%$, pisau disterilkan dengan alkohol 70\% dan memilih tanaman yang tingginya hingga \pm 1 meter. Daun Sansevieria trifasciata yang telah dipotong, dimasukkan ke dalam kantong plastik dan ikat dengan rapi. Sampel dibawa ke laboratorium dan dilakukan pengujian.

Kulturisasi Mikroba pada Media Cair: Isolat Pseudomonas aeruginosa yang tumbuh pada media MCA (Mac Conkey Agar) selama 1 hari (24 jam), diinokulasikan 1/2 cawan pada media NB (Nutrient Borth) 10 gr dalam $250 \mathrm{ml}$ aquades dan diinkubasi selama 1 hari (24 jam). Pada perlakuan nutrisi media yang digunakan adalah NB (Nutrient Borth) dan perlakuan kontrol, Pseudomonas aeruginosa yang tumbuh pada media MCA (Mac Conkey Agar) selama 1 hari (24 jam), diinokulasikan 1/2 cawan dengan menggunakan aquades $250 \mathrm{ml}$. Masing-masing perlakuan diukur $\mathrm{pH}$ 6,6. Untuk menurunkan $\mathrm{pH}$ menggunakan $\mathrm{HCl}$ 1\% (Hidrogen Klorida) dan menaikkan $\mathrm{pH}$ menggunakan $\mathrm{NaOH} 0,1 \mathrm{~N}$ (Natrium Hidroksida).

Inokulasi Mikroba pada Potongan Daun Lidah Mertua (Sansevieria trifasciata): Permukaan daun Sansevieria trifasciata disterilkan dengan alkohol 70\%, dipotong $\pm 1 \times 5 \mathrm{~cm}$ dan disayat dengan skapel steril. Potongan daun Sansevieria trifasciata dicelupkan pada sediaan Pseudomonas aeruginosa medium NB (Nutrient Borth) pada perlakuan nutrisi dan sediaan Pseudomonas aeruginosa pada medium aquades pada perlakuan kontrol.

Pengenceran Pseudomonas aeruginosa : Disiapkan laminar air flow yang dibersihkan dengan alkohol $70 \%$. Disiapkan 6 tabung reaksi steril dan aquades steril, 1 pipet ukur steril $10 \mathrm{ml}, 12$ pipet ukur steril 1 $\mathrm{ml}$, pinset steril, timbangan digital dan sampel perhitungan pertumbuhan koloni pada sediaan daun 
Sansevieria trifasciata. Mengisi tabung reaksi steril dengan $10 \mathrm{ml}$ aquades steril. Ditimbang 1 gr Pseudomonas aeruginosa pada sediaan daun Sansevieria trifasciata dan dimasukkan dalam tabung reaksi yang berisi $10 \mathrm{ml}$ aquades steril. Selanjutnnya dikocok hingga perlahan sampai menjadi suspensi dan tandai tabung dengan lebel $10^{-1}$. Diambil pipet ukur steril $1 \mathrm{ml}$ dan diambil $1 \mathrm{ml}$ suspensi kedalam tabung reaksi $10 \mathrm{ml}$ aquades steri. Dilakukan hal yang sama dengan menggunakan pipet ukur steril $1 \mathrm{ml}$ sampai pengenceran $10^{-6}$. Mengambil $1 / 2 \mathrm{ml}$ masing-masing pengenceran $10^{-5}$ dan $10^{-6}$ dengan pipet ukur steril $1 \mathrm{ml}$. Selanjutnya masukkan ke media MCA (Mac Concey Agar) (dulpo). Cawan petri digoyang seperti angka delapan sampai benar-benar rata pada media.

Seleksi Kemampuan Retting-Embun: Tahap selanjutnya dilakukan seleksi kemampuan mikroba dalam mendegradasi serat kasar daun lidah mertua (Sansevieria trifasciata), dengan cara dimasukkan ke dalam botol dan ditutup dengan plastik.

\section{Hasil dan Diskusi}

Pola Pertumbuhan Pseudomonas aeruginosa pada Sediaan Daun Sansevieria trifasciata: Menurut referensi [10] pola pertumbuhan mikroba digambarkan adanya proses pembelahan sel maupun pertumbuhan bertahap mulai dari awal pertumbuhan sampai dengan akhir yang dibagi menjadi empat fase, yaitu fase lag (penyesuaian), fase eksponensial (peningkatan aktifitas), fase stasioner (keseimbangan) dan fase kematian (penurunan).
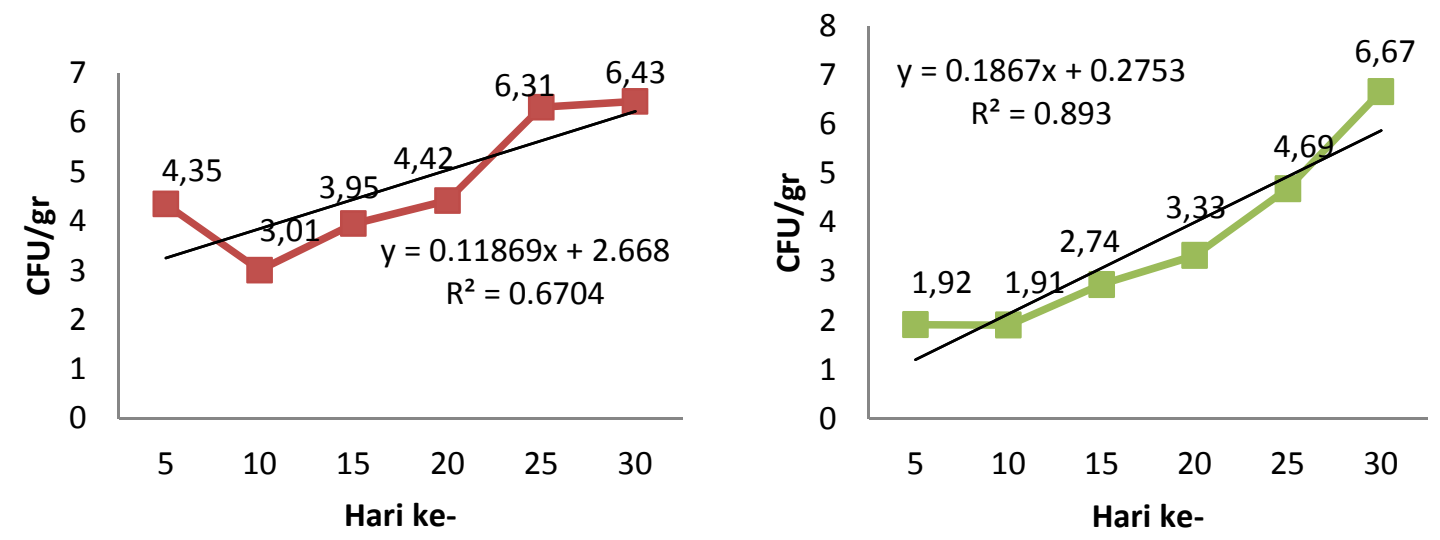

Gambar 1. Grafik pola persamaan regresi pertumbuhan Pseudomonas aeruginosa yang diinokulasikan pada sediaan daun Sansevieria trifasciata.

Pertumbuhan Pseudomonas aeruginosa dengan penambahan nutrisi pada sediaan daun Sansevieria trifasciata pada hari ke-5 diperoleh $2,2 \times 10^{4} \mathrm{sel} / \mathrm{g}$, hari ke-10 mengalami penurunan dengan hasil $1,1 \times 10^{3} \mathrm{sel} / \mathrm{g}$. Kemudian perlakuan dengan tanpa penambahan nutrisi pada hari ke-5 diperoleh hasil jumlah koloni 8,3 $\times 10^{1}$ dan hari ke-10 8,1 × $10^{1}$. Pada kedua perlakuan hari ke-5 sampai hari ke-10 mengalami fase lag atau fase dimana penyesuaian terhadap lingkungan baru.

Fase eksponensial merupakan fase peningkatan bertambahnya sel mencapai kecepatan maksimum. Bertambahnya jumlah sel dipengaruhi atau diimbangan dengan banyak faktor, yaitu bentuk dan sifat mikroorganisme terhadap lingkungannya, medium pertumbuhannya, suhu dan $\mathrm{pH}$ [11][7]. Fase stasioner merupakan fase dimana sumber nutrisi telah mengalami penurunan, adanya senyawa penghambat, kondisi lingkungan yang kurang menguntungkan. Sehingga terjadi keseimbangan aktifitas antara yang mati dengan penambahan individu dan akan membentuk kurva datar. Pada hasil pola 
pertumbuhan Pseudomonas aeruginosa dengan nutrisi dan tanpa nutrisi pada sediaan daun Sansevieria trifasciata selama 30 hari atau 1 bulan tidak menunjukkan adanya fase stasioner sampai fase kematian. Fase kematian merupakan fase berhentinya aktivitas atau pertumbuhan koloni terjadi kematian yang dikarenakan kondisi nutrisi berkurang atau bahkan habis.

Penambahan nutrisi dengan menggunakan NB (Nutrient Broth) memiliki komposisi yang terdiri dari pepton yang berasal dari daging dan ekstrak daging. Komposisi bahan tersebut dibutuhkan oleh bakteri sebagai pertumbuhan sel, sumber energi dan penangkapan elektron. Pepton merupakan protein sebagai sumber karbon, nitrogen dan sulfid yang dibutuhkan oleh bakteri. Sedangkan ekstrak daging sebagai sumber karbon, nitrogen, mineral dan vitamin [9].

Pada perlakuan nutrisi diperoleh persamaan regresi linier $\mathrm{Y}=0,1187 \mathrm{X}+2,668$. Berdasarkan anova regresi pada perlakuan nutrisi diperoleh nilai $\mathrm{F}_{\text {Hitung }} 8,137 \geq \mathrm{F}_{\text {Tabel }} 7,71$, maka $\mathrm{H}_{\mathrm{a}}$ diterima dan $\mathrm{H}_{0}$ yang berarti terdapat pengaruh yang signifikan variabel $\mathrm{X}$ secara simultan terhadap variabel $\mathrm{Y}$. Sehingga dapat disimpulkan adanya pengaruh yang signifikan jumlah sel pada pola pertumbuhan Pseudomonas aeruginosa terhadap penambahan nutrisi.

Pada perlakuan kontrol diperoleh persamaan regresi linier $\mathrm{Y}=0,1867 \mathrm{X}+0,2753$. Berdasarkan uji yang sama pada perlakuan kontrol diperoleh nilai $\mathrm{F}_{\text {Hitung }} 8,137 \geq \mathrm{F}_{\text {Tabel }} 7,71$, maka $\mathrm{H}_{\mathrm{a}}$ diterima dan $\mathrm{H}_{0}$ yang berarti terdapat pengaruh yang signifikan variabel $\mathrm{X}$ secara simultan terhadap variabel $\mathrm{Y}$. Sehingga dapat disimpulkan adanya pengaruh yang signifikan jumlah sel pada pola pertumbuhan Pseudomonas aeruginosa terhadap kontrol atau tanpa penambahan nutrisi.

Kemampuan Pseudomonas aeruginosa pada Retting-embun Serat Kasar Daun: Sanseviaria trifasciata merupakan tanaman serat alam yang memiliki kandungan yang berbeda dari pada jenis tanaman lainnya, karena selulosa yang tinggi dan lignin yang rendah. Selulosa merupakan sebuah polisakarida yang terdiri dari beberapa ratusan, bahkan lebih dari sepuluh ribu ikatan $\beta(1-4)$ unit Dglukosa sehingga membuat serat selulosa menjadi panjang [10]. Tanaman lidah mertua (Sansevieria trifasciata) merupakan jenis tumbuhan serat pada daunnya. Tanaman ini merupakan multiseluler yang sel-selnya dilindungi oleh dinding sel yang kuat. Unsur utama yang dibutuhkan dalam pembuatan serat adalah kandungan selulosa yang tinggi. Terdapat dua macam serat selulosa, yaitu serat selulosa makrofibril dan mikrofibril. Serat selulosa makrofibril akan membentuk sekumpulan sel polisakarida dan protein. Sekumpulan mikrofibril diantara polisakarida dan protein akan membentuk dinding sel yang diperkuat oleh struktur matrik lignin, hemiselulosa dan pektin. Apabila selulosa disintesis akan berkaitan satu dengan yang lainnya membentuk serat selulosa makrofibril [11].

Kemampuan Pseudomonas aeruginosa untuk menghidrolisis (mendegradasi) dinding sel Sansevieria trifasciata dalam proses inkubasi selama 30 hari atau 1 bulan dengan perlakuan penambahan nutrisi dan tanpa penambahan nutrisi menunjukkan adanya perbedaan. Pada hari ke-5 hingga hari ke-10 kedua perlakuan tidak menunjukkan adanya perbedaan, pada daun masih terlihat kaku. Daun Sansevieria trifasciata pada perlakuan kontrol atau tanpa penambahan nutrisi menunjukkan adanya perbedaan pada hari ke-25 yang mana daun tidak kaku dan hari ke-30 daun terlihat sedikit mengembang. Kemudian pada perlakuan penambahan dengan nutrisi, daun Sansevieria trifasciata dimulai tidak kaku pada hari ke-15 dan pada hari berikutnya mulai mengembang sampai hari ke-30.

Pada Gambar 3 dalam inkubasi hari ke-30 daun Sansevieria trifasciata diambil untuk mengetahui kemampuan retting Pseudomonas aeruginosa dalam menghidrolisis dinding sel, sediaan daun tersebut diberi air panas mendidih kemudian dikocok perlahan agar diperoleh skoring serat yang diperoleh. Bakteri yang diinokulasikan pada sediaan daun Sansevieria trifasciata menunjukkan perlakuan nutrisi lebih baik dibandingkan dengan perlakuan kontrol. Dengan penambahan nutrisi serat nampak terurai berwarna putih kecoklatan dibanding dengan perlakuan kontrol atau tanpa penambahan nutrisi yang masih banyak meninggalkan warna hijau.

Untuk dapat tetap hidup, tumbuh dan berkembang bakteri mengubah nutrisi yang ada dilingkungannya sebelum diserap. Dalam kegiatan ini bakteri melibatkan enzim sebagai katalis hayati. Enzim inilah yang mempercepat perubahan subtrat menjadi produk akhir yang akan menjadi sumber energi [12]. 
e-Jurnal Ilmiah BIOSAINTROPIS (BIOSCIENCE-TROPIC)

Volume 5/ No.: 1 / Halaman 59 - 66 / Agustus Tahun 2019

ISSN : 2460-9455 (e) - 2338-2805(p)

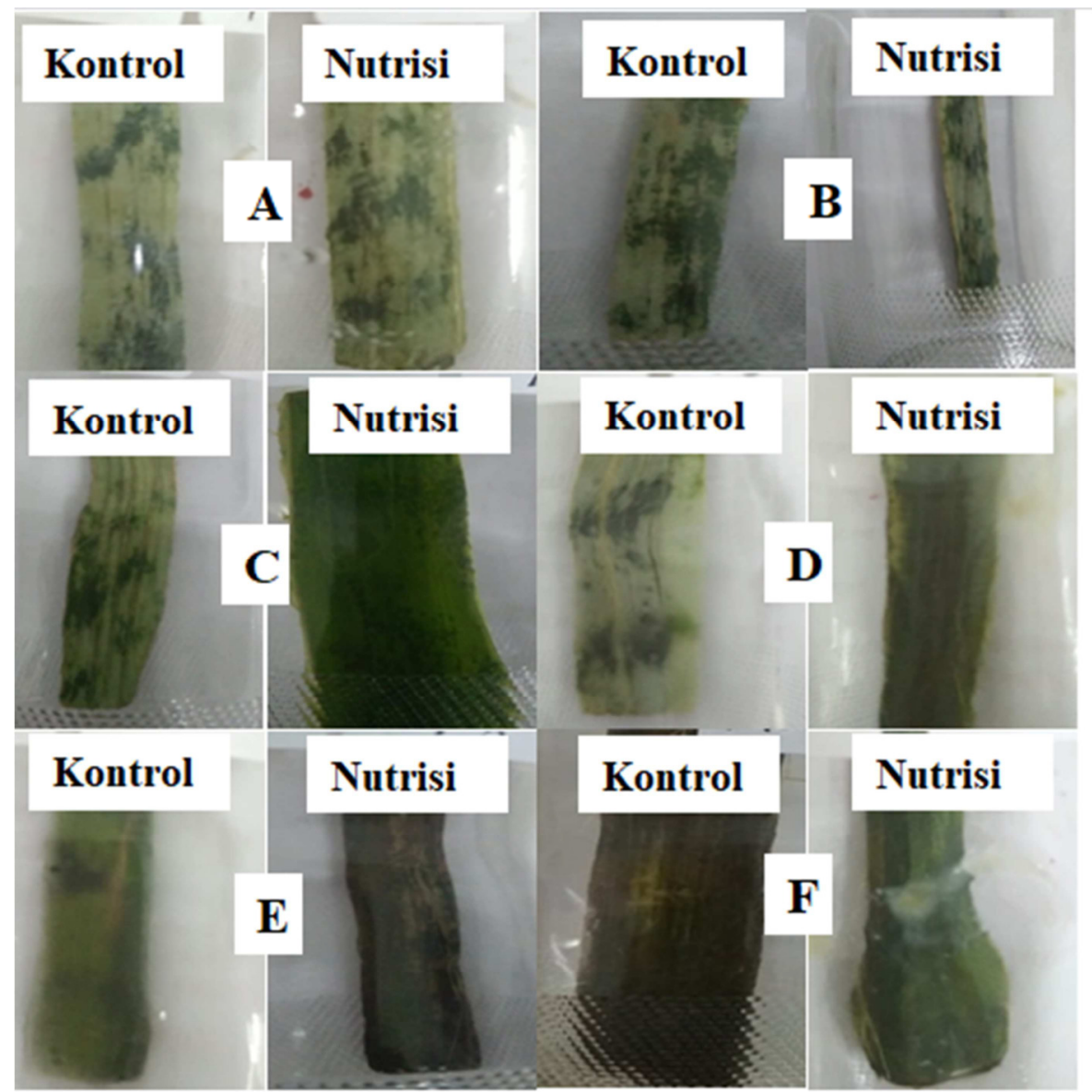

Gambar 2. Hasil pengamatan Pseudomonas aeruginosa yang ditumbuhkan pada sediaan daun Sansevieria trifasciata pada hari ke-5 (A), hari ke-10 (B), hari ke-15 (C), hari ke-20 (D), hari ke-25 (E) dan hari ke-30 (F).
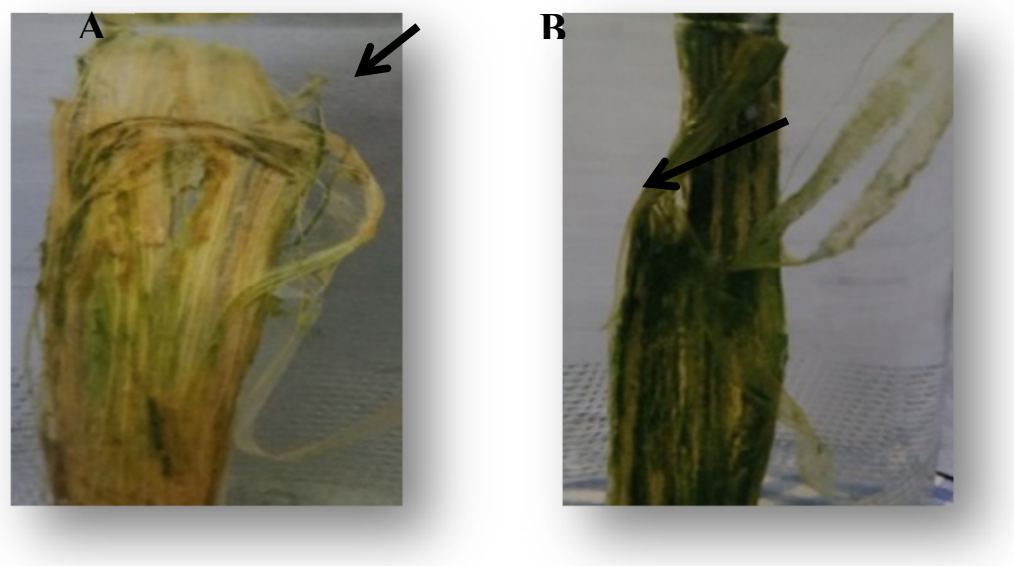

Gambar 3. Serat Sansevieria trifasciata yang telah sepenuhnya terpisah pada perlakuan nutrisi (A) dan Serat Sansevieria trifasciata mulai terpisah satu sama lainnya pada perlakuan kontrol (B). 
Enzim-enzim yang berperan dalam merombak daun Sansevieria trifasciata adalah enzim pektinase untuk menghidrolisis pektin, lignase untuk menghidrolisis lignin dan hemiselulase untu menghidrolisis hemiselulosa [13]. Dalam penelitian ini enzim selulase dihindari, karena dapat merusak serat selulosa.

Untuk dapat tetap hidup, tumbuh dan berkembang bakteri mengubah nutrisi yang ada dilingkungannya sebelum diserap. Dalam kegiatan ini bakteri melibatkan enzim sebagai katalis hayati. Enzim inilah yang mempercepat perubahan subtrat menjadi produk akhir yang akan menjadi sumber energi [12]. Enzim-enzim yang berperan dalam merombak daun Sansevieria trifasciata adalah enzim pektinase untuk menghidrolisis pektin, lignase untuk menghidrolisis lignin dan hemiselulase untu menghidrolisis hemiselulosa [13]. Dalam penelitian ini enzim selulase dihindari, karena dapat merusak serat selulosa.

Kerja enzim sangat dipengaruhi oleh $\mathrm{pH}$, suhu dan senyawa penghambat. Untuk menghasilkan enzim yang spesifik perlu adanya perlakuan yang optimum. Faktor pengaruh yang minimum, mempengaruhi pertumbuhan berhenti dan faktor pengaruh yang maksimum, akan menyebabkan tidak terjadi pertumbuhan karena terganggunya system metabolisme sel [14]. Agar bakteri dapat menghasilkan enzim pektinase dengan baik maka suhu optimum yang digunakan adalah $50^{\circ} \mathrm{C}$ dan $\mathrm{pH} 4,0$ [15]. Pseudomas aeruginosa merupakan jenis bakteri mesofil yang dapat tumbuh dengan baik pada suhu optimum $30-37^{\circ} \mathrm{C}$ dan $\mathrm{pH}$ optimum 6,6. Sehingga Pseudomonas aeruginosa tidak dapat tumbuh dan system metabolisme dan terganggu bila menggunakan pengaturan kinerja penghasil optimum enzim pektinase [14].

Dalam hasil Uji Kemampuan Retting-Embun Pseudomonas aeruginosa pada Serat Kasar Sansevieria trifasciata pada perlakuan nutrisi diperoleh rata-rata dengan skor 3,00 (Tabel 1) yang memiliki arti serat telah sepenuhnya terpisah satu sama lainnya dan perlakuan kontrol diperoleh rata-rata dengan skor 1,5 yang memiliki arti serat mulai terpisah satu sama lainnya. Berdasarkan penelitian yang dilakukan oleh Repeckiene dan Jankauskiene [9], Fusarium lateritium yang diinokulasikan pada sediaan batang rami, sampel potongan diamati dengan Scanning Electron Microscope (SEM) terlihat adanya serat yang terdegradasi dan serat selulosa nampak jelas dengan menunjukkan hilangnya epidermis dan kutikula.

Tabel 1. Uji Kemampuan Retting-Embun Pseudomonas aeruginosa pada Serat Kasar Sansevieria trifasciata

\begin{tabular}{cc} 
Perlakuan & Rata-Rata \\
\hline Nutrisi & 3.00 \\
Kontrol & 1.5 \\
\hline
\end{tabular}

\section{Kesimpulan}

Pola pertumbuhan Pseudomonas aeruginosa untuk menghidrolisis komponen dinding sel Sansevieria trifasciata selama 30 hari dapat menghasilkan fase lag atau fase adaptasi dan fase eksponensial. Dengan penambahan nutrisi dan tanpa penambahan nutrisi pada hari ke-5 sampai hari ke10 mengalami fase lag atau fase adaptasi terhadap lingkungan baru, kemudian fase selanjutnya fase eksponensial dimulai hari ke-10 yang mengalami bertambahnya sel terus meningkat hingga hari ke-30. Pertumbuhan Pseudomonas aeruginosa pada fase eksponensial dapat melunakkan dinding sel Sansevieria trifasciata yang kaku dan kuat, dalam kemampuan retting- embun menghasilkan kualitas serat terpisah satu sama lainnya terlihat berwarna putih kecoklatan pada perlakuan penambahan nutrisi dan serat sebagian mulai terpisah satu sama lain dengan berwarna hijau pada perlakuan tanpa penambahan nutrisi. 


\section{Daftar Pustaka}

[1] Musanif, S. 2011. Karakterisasi Serat Daun 'RZ' (Sansevieria Trifasciata Prain) Sebagai Material Penguat Komposit Berbasis Serat Alam. Jurnal Teknik Mesin. Vol. 1(2):1-4

[2] Putera, R.D.H. 2012. Ekstrasi Serat Selulosa Dari Tanaman Eceng Gondok (Eichornia crassipes) Dengan Variasi Pelarut. Sripsi. Program Studi Teknik Kimia Fakutas Teknik Universitas Indonesia. Depok

[3] Cambell, N.A., and Reece, J.B. 2008. BIOLOGI (Penerjemah: Wulandari, D.T) Edisi Kedelapan, Jilid 1. Penerbit Erlangga. Jakarta

[4] Rahayu, F., Sudjindro, dan Budi, U.S. 2010. Seleksi dan pengujian potensi bakteri Indigenous air rendaman kenaf (Hibiscus cannabinus L.) sebagai baktei selulolitik, pektinolitik, dan lignolitik. Buletin Tanaman Tembakau, Serat \& Minyak Industri. Vol 2 (2): 81-87

[5] Budiyanto, M.A.K. 2004. Mikrobiologi Terapan. UMM PRESS: Malang

[6] Makkadafi, S.P., Hastuti, U.S., Hanzen, WF.E., Asna, PM.AL., dan Febriana. 2017. Isolasi DAN Identifikasi Bakteri Selulolitik dan Pektinolitik dalam Limbah Kulit Singkong Pabrik Tapi di Bndowoso, Jawa Timur. Prosiding Seminar Nasional III Tahun 2017 UMM: Malang

[7] Syauqi, A. 2007. The Unique Carbohydrate Acting Enzyme from sinergystic Fungi in Metagenomic Era. DOI: $10.1340 / R G \cdot 2.2 .36620 .92800$.

URL: https://www.researchgate.net/profile/Ahmad_Syauqi3/publication/312590227

[8] Syauqi, A. 2015. Biostatistika Kuatifikasi Parameter Statistika Survey dan Eksperimen Biologi. FMIPA Universitas Islam Malang. Malang.

[9] Repeckiene, J., and Jankauskiene, Z. 2009. Application of Fungal Complexes to Improve Flax DewRetting. Institute of Botani. Lithuanian Institute of Agriculture. Vol 83 (36): 63-71

[10] Nurhajati, T., Soepranianondo, K., dan Lokapinarsari, W.P. 2011. UJI Aktifitas Pertumbuhan Enterobacter cloaceae Selulolitik Aerob Rumen-1 Isolat Asal Limbah Cairan Rumen Sapi Peranakan Ongole. Jurnal Veteriner. Vol 17(3): 383-388

[11] Wuryanti., Mulyani, N.S., Asy'ari, M dan Sarjono, P.R. 2010. Uji Ekstrak Bawang Bombay sebagai Anti Bakteri Gram Positif Staphylococcus aureus dengan Metode Difusi Cakram. BIOMA. Vol 12(2): 69-73

[12] Sutrian,Y. 2004. Pengantar Anatomi Tentang Tumbuhan (Tentang Sel dan Jaingan). PT. RINEKA CIPTA. Jakarta.

[13] Yudhanto, F. 2016. Proses Pembuatan Plastik Biodegradable Dari Bahan Selulosa Serat Alam (Agave sisalana) dan Chitosan. Penelitian Dosen Muda. Program Studi Teknik Otomotif dan Manufaktur. Universitas Muhammadiyah Yogyakarta: Yogyakarta

[14] Michael, J.P. 1988. Dasar-Dasar Mikrobiologi Jilid 2. Penerbit Universitas Indonesia UI-Press: Jakarta.

[15] Roy, B. 2004. Fundamental Food Microbiology. CRC Press: Boca Raton 